\title{
Two Doctrines of the Unwritten Constitution
}

\author{
PAVLOS ELEFTHERIADIS*
}

\begin{abstract}
The Gina Miller judgment of the United Kingdom Supreme Court will be famous for its protection of the rule of law against an overreaching executive. But it should also be remembered for affirming the systematic nature of the British unwritten constitution. The Supreme Court rejected the older theory of the constitution, on which some of the government's submissions relied, according to which the British constitution is based on the political fact of parliamentary sovereignty (or an equivalent 'rule of recognition') and is for that reason different from that of all other states. This was the view outlined by A. V. Dicey and endorsed by the British legal community for almost a century. The Supreme Court majority (and it is possible that the minority does too) rejected Dicey's constructions and outlined a different theory of the constitution, widely described as the 'common law' theory. For this view, the UK's constitution is higher law made by the conscious decisions of a legislature to create principles of fundamental significance. Joining the EU was a constitutional change brought about by parliament in this way. For this reason, withdrawal from the EU must also be a decision of the legislature by way of an act of parliament. The Supreme Court considers the unwritten constitution to be a system of principles whose origins lie in the legal transformation of the United Kingdom three centuries ago by way of the Bill of Rights 1688, the Act of Union 1707 and other constitutional statutes that created the higher law of the constitution.
\end{abstract}

\section{Introduction}

In the Gina Miller judgment of January 2017 the United Kingdom Supreme Court addressed the question of the procedural means of the United Kingdom's withdrawal from the European Union following the referendum result of June 2016. ${ }^{1}$ The question arises out of the particular mechanism provided for withdrawal by the Treaty on the European Union. Article 50 of the Treaty requires a Member State to give notice of its intention to withdraw and thus starting a two-year process of negotiations. ${ }^{2} \mathrm{~A}$ key aspect of the mechanism of withdrawal under

\footnotetext{
*Associate Professor of Law and Fellow and Tutor in Law, Mansfield College, University of Oxford.

${ }^{1} R$ (on the application of Miller and another) v. Secretary of State for Exiting the European Union [2017] UKSC 5; [2017] 2 WLR 583; [2017] WLR (D) 53, SC(E).

${ }^{2}$ For the various ways Article 50 is supposed to work see Ava Maria Poptcheva, 'Article 50: Withdrawal of a Member State from the EU', Brussels: European Parliamentary Research Service, February 2016 and House of Lords European Union Committee, The Process of Withdrawing from the European Union, $11^{\text {th }}$ Report of 2015-
} 
Article 50 is the fact that if at the end of two years there is no withdrawal agreement or no agreement to extend time, then the member state leaves the EU at once, without an agreement. This means that at that point the treaties shall 'cease to apply.

The government argued that a statement by the government was enough to start the process. Parliament would be involved at a later stage, when the European Communities Act 1972 would be repealed. The government argued that the decision to leave the EU had already been taken by the people, so there was nothing more for Parliament to decide. Moreover, the notification of the intention to withdraw was within the government's prerogative, as a matter of foreign affairs. In any event, the government said, the decision to notify the intention to withdraw would only develop legal effects in international law.

The two main applicants, Gina Miller and Deir Dos Santos, disagreed, making two separate applications for judicial review - that were later joined by the High Court. They both claimed that a decision by parliament was a legal pre-requisite for the United Kingdom to give its notice of an intention to withdraw. The two applicants argued that the eventuality of automatic withdrawal had to be authorised by an act of parliament, before the process was started. Otherwise, the actions of ministers in issuing the notification could potentially lead to the cancellation in effect of statutory rights, something not permitted under standard principles of public law. ${ }^{3}$

At first instance, the High Court, unanimously, rejected the government's arguments. ${ }^{4}$ It reached its decision on the well-established principle that the powers of the royal prerogative were not capable of amending or frustrating an act of parliament or removing statutory rights. The High Court concluded:

'In our judgment, the clear and necessary implication from these provisions taken separately and cumulatively is that Parliament intended EU rights to have effect in domestic law and that this effect should not be capable of being undone or overridden by action taken by the Crown in exercise of its prerogative powers.... We arrive at this conclusion and reject the Secretary of State's submission by interpreting the ECA 1972 as a statute which introduces EU rights into domestic law and must be taken to cover the field. The ECA 1972 cannot be regarded as silent on the question of what happens to EU rights in domestic law if the Crown seeks to take action on the international plane to undo them. ${ }^{5}$

\footnotetext{
2016 session. For the background to the referendum and its effects see Paul Craig, 'Brexit: A Drama in Six Acts' 41 European Law Review (2016) 447-468.

${ }^{3}$ This argument was first made a few days after the referendum in a blog post by three leading academics in constitutional law Nick Barber, Jeff King, Tom Hickman, 'Pulling the Article 50 'trigger': Parliament's Indispensable Role', United Kingdom Constitutional Law Blog, June 27, $2016<$ http://wp. me/p1cVqo-19p>. ${ }^{4} R$ (on the application of Miller and another) $v$ Secretary of State for Exiting the European Union [2016] EWHC 2768 (Admin).

${ }^{5} R$ (on the application of Miller [2016] EWHC 2768 (Admin), par. 94 (Lord Thomas CJ, Sir Terence Etherton MR, Lord Justice Sales).
} 
The government appealed and the case was transferred directly to the Supreme Court, which heard the case in an unprecedented eleven member panel.

The Supreme Court decided, by a majority of eight to three, that parliamentary authorisation was indeed required. ${ }^{6}$ The court also ruled unanimously that the Sewell convention on the relations between the Westminster Parliament and the devolved parliaments is merely a convention, which cannot be enforced by the courts (something on which I will not make any further comment here for reasons of space). But the Court reached those judgments while offering a very general interpretation of the British constitution. The case turned not only on the wording of the European Communities Act 1972 but also on the clash between two rival doctrines of the unwritten constitution. I shall call them for convenience the 'simple sovereignty' view and the 'common law' view. The majority sided, once again, with the common law view, which is now the dominant theory of the British constitution. But in order to explain the constitutional significance of the decision, we need to take a close and patient look at the parties' arguments. ${ }^{7}$

\section{The Government's Case at the Supreme Court}

At the Supreme Court the the government's focused on the way in which EU law became part of the law of the United Kingdom. The government attacked the core of the High Court's reasoning in the following way. It argued that EU law rights were not comparable to UK statutory law. Because they had a foreign origin which always required some domestic mediation for their legal effect and implementation, they were never statutory rights in full. Hence, their potential abolition through executive action through the notification of withdrawal from the EU under Article 50 TEU, was lawful. It could be distinguished from the principle established in Fire Brigades Union, that the royal prerogative, the ancient powers of the executive that have not yet been put under any statutory framework, cannot amend statutory rights. ${ }^{8}$ Because EU law rights were not full statutory rights, they could be abolished through executive action.

In order to support this construction the government claimed that the European Communities Act 1972 incorporated the EU treaties into EU law in a very particular way. The Act did not transform EU law into a 'source' of United Kingdom law. The government's case was that the effect of Treaties, regulations and directives of EU law was always 'contingent' on the British government continuing to approve them. The direct effect and supremacy of EU law, which the UK courts had accepted for forty four years on the basis fo the European Communities Act 1972, was therefore illusory or at least superficial. It had always been

\footnotetext{
${ }^{6}$ The subsequent parliamentary bill to authorise notification met with the very wide approval of the House of Commons, since both main parties, the Conservative party and the Labour party, voted in favour. At the time of writing the Bill is being debated in the House of Lords.

${ }^{7}$ For further analysis of the judgment see Alison Young ' $R$ (Miller) $v$ Secretary of State for Exiting the European Union: Thriller or Vanilla?' 42 European Law Review (2017, forthcoming) and Paul Craig, 'Miller, Structural Constitutional Review and the Limits of Prerogative Power' (forthcoming).

${ }^{8} R v$ Home Secretary, ex $p$ Fire Brigades Union [1995] 2 AC 513.
} 
conditional on the British government's continuing wish to be a member. Because the government's wish had been to remain a member of the club throughout this time, EU law applied, but not otherwise.

The government's argument compared the EU treaties to treaties of double taxation under the Taxation (International and Other Provisions) Act 2010. This Act provides that treaties may have domestic legal effects only as long as the government wishes to continue the operation of a bilateral treaty. If the government withdraws form a taxation treaty, then the corresponding domestic rights will disappear. The same should apply with EU law. In his submissions, the Secretary of State summarised this reading of the European Communities Act 1972 as follows:

It follows that such domestic legal rights and obligations as exist through the conduit of the [European Communities Act 1972] from to time are contingent. They are contingent on the alteration of those rights and obligations (including their removal) by the Government engaging in the processes for negotiating, agreeing and voting on changes to the EU legal regime - all of which involves exercising the Government's prerogative powers.

The Government's case rested thus on the view that the dualist approach of the British constitution towards international law prevented EU from becoming a 'source' of UK law. This was an unusual interpretation of dualism, since this is precisely a doctrine of the mode by which international law becomes binding domestically. Nevertheless, the government's argument was that the the European Communities Act 1972 and the subsequent developments, for example the European Union 2011 Act, which affirmed in section 18 that the status of EU law is dependent on UK acts of parliament, meant that EU law was not really law in the United Kingdom. Therefore, the EU treaties, any secondary legislation and Court of Justice judgments were not really UK law, because they were foreign imports, always at the mercy of executive's discretion. ${ }^{9}$

The government's case concluded:

Whichever method of incorporation is chosen, the essence of dualism is that the domestic statute is the conduit through which international legal rights and obligations are given effect in domestic law. This is the case with ambulatory legislation, such as s. 2(1) [of the European Communities Act 1972], as with other models. In accordance with conventional dualist theory, the function of s. 2(1) ECA is to implement into domestic law the EU-related treaty obligations which the

\footnotetext{
${ }^{9}$ Although the government's case does not go that far, one could interpret this construction as follows. When the UK participated in European Union law-making processes, when for example the UK Commissioner voted in the commission, or when government ministers voted in the Council or when members of the European Parliament voted in parliament, their actions were always a manifestation of the 'royal prerogative'. Although only ministers acted in the name of the British government, both Commissioners and MEPs must have been acting on the condition that the government tolerated their actions and accepted the resulting EU laws.
} 
Government has entered into, from time to time, on the international plane. It is the legislative mechanism by which those obligations are given effect in domestic law.

The government's case did not discuss the possibility that the European Communities Act might have taken a different position to EU law, than that taken for international law, or that subsequent acts of parliament might have done that. The government's submission made little or no reference to most of the well-known cases of the House of Lords and the United Kingdom Supreme Court discussing how EU law has become part of the law of the United Kingdom. ${ }^{10}$

Some of the government's arguments were inspired by an argument made by legal philosopher and constitutional expert John Finnis. In a powerful lecture and in a subsequent published essay, Professor Finnis argued that the effect of European Union law in the UK had been minimal. ${ }^{11} \mathrm{He}$ offered a highly original interpretation of the European Communities Act, which departed from current legal orthodoxy on EU law in Britain (and did not cite the recent Supreme Court cases on the place of EU law in the UK). Finnis argued that: 'our sovereign parliament has rigorously abstained from enacting that we are to be or are members of the European Communities or Union or parties to their Treaties'. ${ }^{12}$ He thus compared the 1972 Act to the Taxation (International and Other Provisions) Act 2010 and argued that its function had been 'to enable the United Kingdom to comply with its international, European obligations to the citizens of Britain and other member states (and thus secure the rights of those citizens correlative to those obligatoins) if and when those obligations and rights arose as the effect of our Government's choice to ratify the Treaty of Accession whereby the United Kingdom joined the European Treaties and Communities' ${ }^{13}$ In effect, for Finnis the role of EU

\footnotetext{
${ }^{10}$ See for the place of EU law in the united Kingdom the recent cases Pham $v$ Secretary of State for the Home Department [2015] UKSC 19, [2015] 1 W.L.R. 1591 [2015] 2 C.M.L.R. 49, where Lord Mance said (at par. 76) that EU law is part of the law of the UK because Parliament legislated in the European Communities Act 1972 that it should be. See also R. (on the application of Buckinghamshire CC) $v$ Secretary of State for Transport [2014] UKSC 3; [2014] 1 W.L.R. 324, Assange v Swedish Prosecution Authority [2012] 2 AC 471.

${ }^{11}$ John Finnis, 'Brexit and the Balance of Our Constitution', Policy Exchange, London, 2 December 2016, available at: < https://policyexchange.org.uk/judicial-power-project-john-finnis-on-brexit-and-the-balance-of-ourconstitution/ >

${ }^{12}$ Finnis, 'Brexit and the Balance of our Constitution', p. 13. The statement runs contrary to the statutory record. Section 1 of the European Communities Act 1972 lists eighteen different treaties and agreements that are given effect through acts of parliament in the UK, in order for the UK to continue being a member.

${ }^{13}$ Finnis, 'Brexit and the Balance of our Constitution', p. 13. The government's appeal also referred to similar arguments made by Professor Adam Tomkins in a post in/on? Verfassungsblog.de on 6 November 2016, where he said that 'the legal basis of the rights and obligations we enjoy under EU law is EU law not the European Communities Act. The ECA is merely the vehicle by which those rights and obligations are translated into enforceable rights and obligations...' John Finnis' reading of EU law is similar to the view expressed by Richard Ekins in 'Constitutional Principles in the Laws of the Commonwealth' in John Keown and Robert P. George (eds.), Reason, Morality, and Law: The Philosophy of John Finnis, Oxford University Press, 2013, p. 397-412. For Ekins (at p. 398): 'at no time have the criteria for legal validity in the EU been accepted on their own terms by the political community of the UK. Rather, that community, by way of a particular rule valid by reference to its criteria (in relevant part; what the Queen in Parliament enacts is law), made provision for the content of another legal system to have effect within its own legal system. The rules of European law were not made in accordance with criteria of validity in force in the UK at the time of making'.
} 
law in the UK was conditional on the government continuing to wish to participate in the EU, which remained a matter for foreign affairs.. Finnis made no attempt to explain the voluminous case law that had discussed EU law in the UK and which had never set out a theory of conditional membership in the EU. In any event, the government adopted many of these arguments.

\section{The Two Applicants' Case}

The case for the lead claimant, Gina Miller, was in line with the High Court's judgment. David Pannick QC for Gina Miller claimed that the European Communities Act 1972 had created statutory rights based on EU treaties that could not be removed by the exercise of the prerogative alone. Her case was that the Act had made a 'major constitutional change', by giving direct effect in domestic law 'to rights developed at international level, with such rights having priority over other statutes (pre-existing and subsequent), and with their scope and effect being determined with binding effect by an international court'.

The submission accepted the standard account of the place of European Union law in the UK, as one finds them in the case law and the academic literature. The lead applicant relied on the case of Thoburn $v$ Sunderland City Council, where the High Court explained that the European Communities Act was a 'constitutional statute', which could not be impliedly repealed. ${ }^{14}$ The lead applicant referred to the Supreme Court judgment, in the Buckinghamshire (or better known as the ' $H S{ }^{\prime}$ ') case, that unanimously endorsed the ruling in Thoburn. ${ }^{15}$ The e joint judgment of Lords Neuberger and Mance in Buckinghamshire, with whom all the other judges agreed, concluded as follows:

The United Kingdom has no written constitution, but we have a number of constitutional instruments. They include Magna Carta, the Petition of Right 1628, the Bill of Rights and (in Scotland) the Claim of Rights Act 1689, the Act of Settlement 1701 and the Act of Union 1707. The European Communities Act 1972, the Human Rights Act 1998 and the Constitutional Reform Act 2005 may now be added to this list. ${ }^{16}$

The court ruled that the European Communities Act had created a special process of lawmaking, whereby EU law ordinarily takes precedence over subsequent law. This constitutional innovation was not against parliamentary sovereignty because it had been made pursuant to parliamentary sovereignty: it was made through an act of parliament, like all constitutional change should. Parliament could always amend it by a new act of parliament.

, The submission criticised the government for failing to recognise the 'exceptional nature' of the 1972 Act, which incorporated into domestic law a body of rights under EU law but also amended the operation of the dualist principle, to the effect that it opened up UK

\footnotetext{
${ }^{14}$ Thoburn v Sunderland City Council [2003] QB 151, 186-187, paragraphs 62-63.

$15 R$ (Buckinghamshire County Council and others) v Secretary of State for Transport [2014] UKSC 3, [2014] WLR (D) 28. The case was known as HS2 Action Alliance, by the name used during the proceedings, but the Supreme Court judges refer to the case - as is conventional - by the name used in the official law reports.

${ }^{16} R$ (Buckinghamshire County Council and others) v Secretary of State for Transport par. 207.
} 
law to directly effective EU law. She also reminded the government that the 1972 Act has enjoyed 'constitutional status' by virtue of numerous judgments of the courts, including of the House of Lords and the UK Supreme Court, and that as a result it could not be impliedly repealed. It can only be repealed explicitly. It followed from all these points that the Article 50 notification required statutory authorisation, since the automatic withdrawal that could follow it would cause those statutory rights (or at least some of them) to be destroyed or frustrated.

The second claimant, Dos Santos, endorsed all of the above arguments and put somewhat more emphasis on the constitutional point. His representatives argued that notification of the UK's intention to withdraw from the EU would be a 'quasi-legislative' step, in that it would effectively strip of meaning the European Communities Act 1972. The Dos Santos submissions (at par. 45) drew attention to the fact that 'the plain intent and effect of the 1972 Act was to make legally effective the United Kingdom's membership of the EU and to bring about the constitutional change in the United Kingdom associated with EU membership'.

\section{The Supreme Court Majority}

The court was split eight to three. The majority, accepted the applicants' arguments. It did so, however, by placing great emphasis on the constitutional arguments. The majority ruled that the European Communities Act 1972 did more than give effect to the then EEC treaties. It authorised, the court said, 'a dynamic process by which, without further primary legislation (and, in some cases, even without any domestic legislation), EU law not only becomes a source of UK law, but actually takes precedence over all domestic sources of UK law, including statutes'. ${ }^{17}$ This means that 'in constitutional terms the effect of the 1972 Act was unprecedented'. ${ }^{18}$ The ruling was thus in line with both the standard case law of the UK courts and the constitutional requirements of direct effect and supremacy as outlined by the Court of Justice of the European Union. The majority referred to the famous Factortame cases of the House of Lords, which confirmed that EU law took precedence over all domestic sources of UK law, including statutes. ${ }^{19}$ In that case the House of Lords had interpreted this case as being fully in accordance with parliamentary sovereignty, because parliament created the 1972 Act like any other statute. Reflecting on Factortame, the Supreme Court majority concluded that 'we would not accept that the so-called fundamental rule of recognition (i.e. the fundamental rule by reference to which all other rules are validated) underlying UK laws has been varied by the 1972 Act or would be varied by its repeal'. ${ }^{20}$ Everything that took place was in accordance with the doctrine of parliamentary sovereignty. The majority took the 1972 Act to have created a new method of making law in the UK, where 'the EU institutions' are

\footnotetext{
17 Miller, par. 60.

18 Miller, par. 60.

${ }^{19} R$ v Secretary of State for Transport, ex p. Factortame Ltd (No 2) [1991] 1 AC 603 and (No 5) [2000] 1 AC 524.

${ }^{20}$ Miller, par. 60.
} 
the relevant sources of that law. The effect of the Act is to constitute EU law an independent and overriding source of domestic law'. ${ }^{21}$

The court also noted that the European Communities Act 1972 introduced a process of incorporating EU law in an entirely different way to that of the double taxation treaties with which the government submissions compared it. The European Communities Act 1972 incorporates rights and obligations that arise in EU treaties unconditionally, as long as these treaties are listed in section 1(2) of the European Communities Act. Every time a new Treaty is signed, the list has to be updated by a new act of parliament (most recently the European Union (Croatian Accession and Irish Protocol) Act 2013)..The United Kingdom's EU membership has been continuously renewed by a new act of parliament every time there is a new Treaty. (so the idea that the European Communities Act as originally made in 1972 is the same one as the one valid in 2017 is false.

By contrast, any changes to double taxation treaties, under the Taxation (International and Other Provisions) Act 2010, are merely to be listed by the government in an Order in Council, i.e. an act of the executive. ${ }^{22}$ The statutory scheme is therefore entirely different in the two cases. It is clear for the Supreme Court majority that 'the continued existence of the conduit pipe, as opposed to the contents which flow through it, can be changed only if Parliament changes the law'. ${ }^{23}$

The government's submission was thus rejected not only because the European Communities Act had created substantive rights which cannot be repealed by executive action under the Royal prerogative (as had been held by the High Court) but for the further reason that the Act had also created a new 'constitutional process for making law in the United Kingdom' which could not be repealed by executive action. ${ }^{24}$ The court concluded that it was impossible to interpret the 1972 Act as empowering the executive to abolish this process unilaterally:

The EU Treaties as implemented pursuant to the 1972 Act were and are unique in their legislative and constitutional implications. In 1972, for the first time in the history of the United Kingdom, a dynamic international source of law was grafted onto, and above, the well-established existing sources of domestic law: Parliament and the courts.... Bearing in mind this unique history and the constitutional principle of Parliamentary sovereignty, it seems most improbable that those two parties had the intention or expectation that ministers, constitutionally the junior partner in that exercise, could subsequently remove the graft without formal appropriate sanction from the constitutionally senior partner in that exercise, Parliament. ${ }^{25}$

\footnotetext{
${ }^{21}$ Miller, par. 65.

22 Miller par. 98.

${ }^{23}$ Miller, par. 84, see also par. 52, 53 and 79.

${ }^{24}$ Miller, par. 61.

${ }^{25}$ Miller, par. 90.
} 


\section{The Minority Opinion}

Lord Reed put forward a lengthy and spirited opposition to the judgment of the majority. He agreed with the government's view on some of the effects of the 1972 Act. His first argument - accepting in effect the points earlier made by John Finnis - was that the European Communities Act 1972 did not impose any requirement that the UK should be a member of the EU. Membership was always conditional. It depended on the government wishing to remain a member of the club. If so, then all the effects of EU law were also conditional too. This was a matter for the government. It was a matter of foreign affairs. For Lord Reed a close reading of the European Communities Act 1972 revealed that the Act did not wish to change the well-established doctrine that adhering to treaties is always a matter for the government. As a result, the European Communities Act did not have the constitutional significance claimed by the majority. It did not create a new 'source of law'. And even if it did create such a source, it would be a source only if and as long as the condition of membership was met. Lord Reed said:

it is a basic principle of our constitution that the conduct of foreign relations, including the ratification of treaties, falls within the prerogative powers of the Crown. That principle is so fundamental that it can only be overridden by express provision or necessary implication, as is accepted in the majority judgment at para. 48. No such express provision exists in the 1972 Act. Nor do its provisions override that principle as a matter of necessary implication. ${ }^{26}$

In Lord Reed's view the effect of the Act was always conditional on the UK's remaining a member of the EU, which was a matter for executive decision. Dualism was therefore still intact, without any amendment.

Lord Reed's second argument touched on the theory of a 'rule of recognition'. He said that EU law was in truth a form of delegated law, which was entirely dependent on the act of parliament that enabled it. He concluded that since the effect of EU law in the UK 'is entirely dependent on the 1972 Act, no alteration in the fundamental rule governing the recognition of sources of law has resulted from membership of the EU, or will result from notification under article 50'. ${ }^{27}$ It followed for Lord Reed that EU law is not an 'independent source of domestic law' and the 1972 Act is not of fundamental constitutional significance. His conclusion was as follows:

The implication is that EU law is not itself an independent source of domestic law, but depends for its effect in domestic law on the 1972 Act: an Act which does not confer effect upon it automatically and without qualification, but has to be interpreted and applied in the wider context of the constitutional law of the UK. Accordingly, although no-one can doubt the importance of EU law, the effect given to it by the 1972 Act has

\footnotetext{
${ }^{26}$ Miller, par.194.

${ }^{27}$ Miller, par. 177.
} 
not altered any fundamental constitutional principle in respect of the identification of sources of law. ${ }^{28}$

The term 'source' seems to refer here to the identity of law-maker not the type of law - hence sources of law remain parliament and the courts. That was not changed by the 1972 Act. For these and other reasons Lord Reed held that the government was right to seek notification without authorisation by an act of parliament. Lords Carnwath and Hughes agreed with him in shorter judgments of their own.

\section{The Doctrine of Simple Sovereignty}

One could read the case as turning on the interpretation of the 1972 Act and the way in which it affects or does not affect the royal prerogative in foreign affairs. The majority of the Supreme Court read the Act as affirming membership in the EU and therefore limiting the prerogative, while the minority did not. From this all sorts of consequences followed. For the majority the 1972 Act brought about the direct effect and supremacy of the Treaties which established EU law as a unique and new 'source' of law in the United Kingdom. For the minority the 1972 Act did nothing of the sort. It introduced EU law on the condition that the executive would continue to affirm membership through its standard powers of foreign affairs. This account of the case, however, would in my view be inaccurate and incomplete.

There is a deeper dimension to the case, which runs parallel to the question of statutory interpretation. Although the disagreement on the interpretation of the 1972 Act is real, it is not the only question dividing the claimant and the government's positions. The two views rely on two rival doctrines of the unwritten constitution.

The government's submissions relied, at least implicitly, on a doctrine which I shall call for convenience 'simple sovereignty'. ${ }^{29}$ This theory originated in the work of A. V. Dicey, who believed that the British constitution was unique among all European constitutions in including only a small number of relatively simple principles: parliamentary sovereignty, the rule of law, constitutional conventions. ${ }^{30}$ Dicey's view was that in the United Kingdom there was not strictly speaking a 'higher law' of the constitution outlining, for example principles for the separation of powers, the role of the courts, or for a bill of rights.. The most important rule was the simple rule of parliamentary sovereignty as a formal mechanism of law-making. For Dicey 'the Queen in Parliament', i.e. the processes by which the House of Commons, the House of Lords and the Monarch jointly make an act of parliament and are the highest law-

\footnotetext{
${ }^{28}$ Miller, par. 228.

${ }^{29}$ One of the main defenders of the theory calls it 'this simple English theory of parliamentary sovereignty' in William Wade, 'The Basis of Legal Sovereignty' [1955] Cambridge Law Journal, 172, at 184.

${ }^{30}$ A. V. Dicey, Introduction to the Study of the Law of the Constitution, $8^{\text {th }}$ ed. (London: Macmillan, 1915 reprinted Indianapolis, IN: Liberty Fund, 1982), henceforth 'Introduction'. For a sophisticated defence of this view see Jeffrey Goldsworthy, The Sovereignty of Parliament: History and Philosophy (Oxford: Clarendon Press, 1999). For the logical and doctrinal problems with Dicey's account see Pavlos Eleftheriadis, 'Parliamentary Sovereignty and the Constitution' 22 Canadian Journal of Law and Jurisprudence (2009) 267-290 and Pavlos Eleftheriadis, 'Law and Sovereignty' 29 Law and Philosophy (2010) 535-569.
} 
maker. The United Kingdom does not have and does not need any higher laws regarding rights or the separation of powers, according to this view. A process of making acts in parliament was sufficient for constitutional purposes. Dicey noted that other nations had relied on other institutional mechanisms in order to achieve the same constitutional goals. They used what British constitutionalists still describe as 'rigid' and 'codified' rules to achieve the same political aims. Dicey was not shy about the reason: the British did not need them because they had a happier history of government, where the tradition from the omnipotent sovereign to the modern doctrine had been more or less seamless. Dicey writes: '[t]he historical reason why Parliament has never succeeded in passing immutable laws, or in other words, has always retained its character of a supreme legislature, lies deep in the history of the English people and in the peculiar development of the English constitution.' ${ }^{31}$

The same idea was refined and elaborated by William Wade in his famous and very influential article 'The Basis of Legal Sovereignty'. ${ }^{32}$ Wade insisted that parliamentary sovereignty amounted to a common law rule that required that judges should always obey statutes. Courts could never challenge the validity of a statute. This meant that a later statute would as a matter of logic always amend an earlier one with contradictory or competing content, so that it was impossible for any laws to be 'entrenched'. ${ }^{33}$

It follows from this simple principle that one parliament cannot bind another that 'there is one, and only one, limit to Parliament's legal power: it cannot detract from its own continuing sovereignty'. ${ }^{34}$ So for Dicey there is no distinction between 'constitutional' and 'ordinary' statutes in the British constitution. All acts of parliament had the same force which they derive from the way they were made (hence the Parliament Acts of 1911 and 1949 created for Wade a new kind of delegated legislation). Wade observed that the rule of parliamentary sovereignty was not based on any legal rule. It is 'a rule which is unique in being unchangeable by Parliament - it is changed by revolution, not be legislation; it lies in the keeping of the courts, and no Act of Parliament can take it away from them' ${ }^{35}$

Wade thus famously concluded that parliamentary sovereignty could not be legally amended. ${ }^{36}$ He concluded that:

if no statute can establish the rule that the courts obey Acts of Parliament, similarly no statute can alter or abolish that rule. The rule is above and beyond the reach of statute, as Salmond so well explains, because it is itself the source of the authority of statute.

\footnotetext{
${ }^{31}$ Dicey, The Law of the Constitution, 25, n. 48. On Dicey's views see the extremely helpful analysis by John Allison, The English Historical Constitution: Continuity, Change and European Effects (Cambridge: Cambridge University Press, 2007) 103-126. For the history of the doctrine of parliamentary sovereignty and Dicey's role in formalising it see Jeffrey Goldsworthy, The Sovereignty of Parliament: History and Philosophy (Oxford: Oxford University Press, 1999).

32 Wade, 'The Basis of Legal Sovereignty' 172.

${ }^{33}$ Wade, 'The Basis of Legal Sovereignty' 174.

${ }^{34}$ Wade, 'The Basis of Legal Sovereignty' 174.

${ }^{35}$ Wade, 'The Basis of Legal Sovereignty' 189.

${ }^{36}$ H. W. R. Wade, 'The Basis of Legal Sovereignty' (1955) Cambridge Law Journal 172, at 187.
} 
This puts it into a class by itself among rules of common law, and the apparent paradox that it is unalterable by Parliament turns out to be a truism. ${ }^{37}$

Wade argued that the rules constituting Parliament were a matter of fundamental presuppositions that were beyond any legal powers. They were for him a 'constitutional fundamental' that could not be lawfully changed even by an Act of Parliament. So he wrote that: 'it is futile for Parliament to command the judges not to recognize the validity of future Acts of Parliament which conflict with a Bill of Rights, or with European Community law, if the judges habitually accept that later Acts prevail over earlier Acts and are determined to go on doing so. In this one fundamental matter it is the judges who are sovereign'. ${ }^{38}$ Wade thought that this was the necessary logical corollary of parliamentary sovereignty as a principle of the unwritten constitution.

The legal philosopher H. L. A. Hart gave further theoretical gloss to these views and coined the phrase 'rule of recognition', which has been occasionally mentioned by the Supreme Court. Hart did not say that parliamentary sovereignty was the factual basis of law, as Dicey had said. He offered a more complex factual basis for law, on the basis of a 'union of primary and secondary rule' that is based on some kind of consensus, mostly among legal officials. He considered, following Wade, that the legal system had a foundation in a set of ultimate rules and said that the ultimate rule of a legal system must be a 'rule of recognition' which sets out criteria for the validity of all legal rules, but is subject to no such rule itself. ${ }^{39}$ Hart thus affirmed the views of Dicey and Wade that the ultimate rules of the United Kingdom legal order were not constitutional or legal, but were a matter of political or merely social fact. The principle of sovereignty e was not therefore, strictly speaking, a matter of the common law. It was just a fact of social life.

One very important result of Dicey, Wade and Hart's assumption that there were no higher constitutional laws in the United Kingdom (as those that determine political power in the United States or France), was that British constitutional law had no rules applying to itself. There was no legal mechanism for amending parliamentary sovereignty, for example by way of a constitutional convention or by explicit amendment. Dicey, Wade and Hart therefore agreed that, in legal terms at least, parliamentary sovereignty was a continuing fact of British

\footnotetext{
${ }^{37}$ Wade, 'The Basis of Legal Sovereignty' 187-88. At p. 189 he also said, confusingly, that the doctrine lies in the keeping of the courts' and cannot be altered 'by any authority outside the courts'. For discussion of this question see Goldsworthy, The Sovereignty of Parliament, 243 and 244 at n. 34. Goldsworthy explains that the Hartian doctrine of the rule of recognition as an extra-legal rule works only if the rule is the result of pre-existing and diffuse social behaviour, not a matter of discretion for judges to create as they see fit. Wade's mistake is repeated by John Gardner who writes that: 'In the UK, to recap, what determines the status of certain law as constitutional law is its reception into constitutional law by certain law-applying officials, principally the courts' in Gardner, 'Can there Be a Written Constitution' in Leslie Green and Brian Leiter (eds.), Oxford Studies in Philosophy of Law: Volume I (Oxford: Oxford University Press, 2011) 176.

${ }^{38}$ H. W. R. Wade, Constitutional Fundamentals (London: Stevens, 1980) 26-7. Strictly speaking Wade is wrong. Under the Hartian model of a rule of recognition, no one is sovereign. Everyone is subject to a rule of ultimate law-making.

${ }^{39}$ H. L. A. Hart, The Concept of Law, $2^{\text {nd }}$ ed. (Oxford: Clarendon Press, 1993) 100-110, 149-154
} 
government that could not be legally amended. Only a legal revolution could change the constitution. Parliament therefore was thus de facto omnipotent on everything, except on its own omnipotence. Hart said that the 'legal competence of the supreme legislature itself' depends on the rule of recognition, which sets out the 'ultimate criteria of legal validity'. ${ }^{40}$ Hart's ultimate rule had two possible manifestations. The first was the 'continuing omnipotence of parliament' and the second the 'self-embracing omnipotence, the exercise of which can only be exercised once'. ${ }^{41}$ The 'self-embracing' view meant that parliament could change the terms of its own sovereignty. He concluded, with Dicey and with Wade, that as a matter of fact 'it is clear that the presently accepted rule is one of continuing sovereignty, so that Parliament cannot protect its statutes from repeal'. ${ }^{42}$

I believe that the arguments of the government and the judgment of Lord Reed are made in the shadow of the framework proposed by Dicey and refined by Wade and Hart. The minority seems to take the European Communities Act to have been an ordinary Act of Parliament, like any other. This is what the simple rule of sovereignty tells us must be the case, because Dicey left no room for constitutional statutes (only for constitutional 'facts'). Lord Reed says therefore that just like any statute can enable a minister to enact delegated legislation by way of a statutory instrument, so the European Communities Act gave effect to EU law as made by European institutions, whatever its content 'from time to time'. So he writes that EU law 'like legislation enacted by the devolved legislatures or delegated legislation made by Ministers, is entirely dependent on statute. ${ }^{43}$

Lord Reed seems to endorse the similar distinction drawn by Wade between a sovereign legislature, whose authority is not derived by law (but only by fact), and a subordinate legislature, whose authority is merely legal. Wade had put the distinction as follows: 'The distinction between sovereign and subordinate legislature is therefore this: sovereign legislation depends for its authority on an 'ultimate legal principle', i.e. a political fact for which no purely legal explanation can be given; subordinate legislation depends for its authority on some ulterior legal power for which a legal explanation can be given'. ${ }^{44}$ Applying the same test (without, though, referring to Wade), Lord Reed says that the Westminster parliament is sovereign and the European law-making authorities are subordinate. Their laws are not therefore 'sources' at least not in the required sense set out by Dicey. Lord Reed was here responding to and dismissing an argument by Helen Mountfield QC on behalf of an interested party, to the effect that leaving the EU would be an amendment to the 'rule of recognition'. ${ }^{45}$ Made in those terms, the argument was explicitly relying on

\footnotetext{
${ }^{40}$ H. L. A. Hart, The Concept of Law,148.

${ }^{41}$ Hart, The Concept of Law, 149.

${ }^{42}$ Hart, The Concept of Law, 150. Ronald Dworkin explained the serious flaws with Hart's idea of a rule of recognition under a 'model of rules' in Dworkin, Taking Rights Seriously, revised ed. (London: Duckworth, 1978) pp. 39-45.

${ }^{43}$ Miller, par. 224.

${ }^{44}$ Wade, 'The Basis of Legal Sovereignty' 189.

${ }^{45}$ Miller, par. 223.
} 
Dicey's doctrine for the nature of sovereignty, because it assumed that all constitutional change was a matter of fact.. Mountfield's argument was that just as entering the EU required a legal revolution, exiting it required another one as well. It is important that this argument was not made by the two main claimants. The claimants rejected Wade's analysis. They endorsed instead the rival view of the constitution, the one endorsed by the majority. But Lord Reed responded to Helen Mountfield's argument at length and took the opportunity to affirm Wade's distinctions assuming that the British constitution was a matter of political fact, just like Dicey and Hart had said.

Lord Reed thus said that because EU law derives its status from statute, namely the European Communities Act 1972, it follows that it cannot be a new source of law, i.e. not a source whose origin is traced to ultimate constitutional fact. It also followed that accession to the EU did not create a new rule of recognition. Lord Reed thus concluded that EU law is not and never was an 'independent' source of law. He said that EU law would be an independent source of law only if its authority relied directly on some 'rule of recognition', but instead EU law 'depends on the ultimate rule of recognition'. ${ }^{46}$ For this argument EU law would have enjoyed recognition in the UK as a new source of law not as a result of the European Communities Act 1972, but only because of a newly dominant foundational rule, a new 'rule of recognition' that had crystallised at some point after 1972.. This would have to have been the result of a shift in attitudes, belies and dispositions in the relevant way, as indicated by Hart's theory. But Lord Reed assumes that such a transformation did not happen. ${ }^{47}$

Lord Reed then refers to the rule of recognition by citing the only other reference to the rule of recognition in the history of the UK Supreme Court besides Miller that made by Lord Mance in the European citizenship case of Pham, according to whom 'unless and until the rule of recognition by which we shape our decisions is altered, we must view the United Kingdom as independent, Parliament as sovereign and European Law as part of domestic law because Parliament has so willed. ${ }^{48}$ Lord Mance's account is a well-established account of the effect of EU law in the UK. It is not seen as in any way hostile to EU law. But Lord Reed draws this striking conclusion from Lord Mance's words:

As Lord Mance rightly explained, it follows from the UK's dualist approach to international law that EU law is not one of the sources of law identified by the UK's rule of recognition... [EU law] derives its legal authority from a statute, which itself derives its authority from the rule of recognition identifying Parliamentary legislation as a source of law. The recognition of its validity does not alter any fundamental principle of our constitution. ${ }^{49}$

\footnotetext{
${ }^{46}$ Miller, par. 224.

${ }^{47}$ Thus disagreeing with William Wade, 'Sovereignty: Revolution or Evolution?' 112 Law Quarterly Review (1996) 568-575.

48 Pham v Secretary of State for the Home Department [2015] UKSC 19; 1 WLR 1591, para 80.

${ }^{49}$ Miller, par. 225.
} 
This is a puzzling statement, because the majority in Miller - which includes Lord Mance - said exactly the opposite. ${ }^{50}$ The majority said that EU law is an independent source of law precisely because it was so recognised by the European Communities Act 1972. This is where the majority and the minority differ. They are adopting a different doctrine of the unwritten constitution. Lord Reed assumes, for the reason that I explained above, that the sources of the UK constitution are exhaustively created by a fundamental rule of recognition which is true as a matter of political fact. Since EU law does not derive from that fact, it is not source of law in this sense. In other words, the question dividing the majority and the minority in Miller is, what the 1972 Act was capable of doing - assuming it wanted to do it. Can a statute create new sources of law? This is not just a disagreement about the interpretation of the words of the statute, but about the presuppositions of constitutional principle that determines the effect of a statute's words.

Lord Reed seems to agree with Wade that a sovereign parliament is not subject to law but only to the political fact of a 'rule of recognition'. Lord Reed does not say so explicitly, but his argument assumes so. The underlying premise must be that just like parliamentary sovereignty, the ancient doctrine of dualism according to which international treaties are not binding in the UK until specifically incorporated by statute is a matter of Hart's 'rule of recognition' and not a matter of statutory law. He also assumes that no statute could ever change such a doctrine, because as Wade and Hart explained, no statute can change the rule of recognition. The doctrine of parliamentary sovereignty for this view is beyond law, legally unalterable and inalienable. If any statute tried to change it, for the sake of EU law or another treaty framework, it would fail. It follows that EU law cannot be an 'independent source of law', in the sense given to the term by Lord Reed as something directly deriving form a factual and ultimate 'rule of recognition'. ${ }^{51}$

In other words, precisely because EU law was incorporated through an Act of Parliament, it could not have signalled a change to constitutional fundamentals (because they are a fact-based 'rule of recognition'). If EU law is dependent on the statute, then it is entirely derivative from it and is not an 'independent' source of law. Lord Reed's view is thus similar (although, as we shall see below not identical) to that of Sir William Wade. It assumes that the European Communities Act could not have amended the British constitution, because it could not so amend it. No laws can amend our constitution, conceived as the simple rule of sovereignty. The constitution can only change by political fact as explained by Wade and Hart. Lord Reed seems to agree with this premise, even though it remains unstated, as he relies on precisely a 'continuing view' of simple sovereignty in order to relegate EU law to the status of derivative or secondary law, It is for this reason that Lord Reed's judgment failed to convince the majority. In fact, Lord Reed's judgment as well as Wade's argument and John Finnis'

\footnotetext{
${ }^{50}$ The majority said: 'So long as the 1972 Act remains in force, its effect is to constitute EU law an independent and overriding source of domestic law'; Miller par. 65.

${ }^{51}$ Miller, par. 228.
} 
revival of them, are more than twenty years out of date: they fail to take into account the legal process whereby EU law has become part of the law of the United Kingdom. ${ }^{52}$

\section{The Doctrine of the Legal Constitution}

The majority view rejects this interpretation of the unwritten constitution in its entirety. It says that The British constitution is not as Dicey and Wade described it. Many scholars have observed that Dicey's account seemed plausible only because it relied on an ambiguity of the term 'Parliament' or 'Queen in Parliament'. ${ }^{53}$ It could be a matter of fact, or it could be a matter of law. But the factual constitution is something very different from the legal constitution. Whatever the theoretical position, the United Kingdom Courts have now effectively abandoned the doctrine of simple or factual sovereignty as outlined by Dicey, Wade and Hart. They have done so precisely in order to accommodate the conscious political decisions of parliament through which the law-making process of the United Kingdom has changed. The dominant view of the United Kingdom courts is that a rival doctrine, that of 'legal constitution'. As the majority in Miller eloquently explains, accession to the European Union brought about a legal change in the constitution. The majority also assumes that the British constitution is not a simple fact, but is a matter of law, which like all law in a democratic society, is open to conscious deliberation and change.

As Wade had predicted, the simple sovereignty theory had great trouble accommodating the supreme effect of European Community law, which the Court of Justice of the European Communities had declared to be a fundamental doctrine of the European legal order since the 1960s. Faced with this dilemma, the UK courts abandoned the simple sovereignty view, precisely in order to give full effect to the conditional supremacy of EU law in common with all other member states.

In the case of Factortame the House of Lords did what Sir William Wade in 1955 said was impossible. ${ }^{54}$ The court declared that the European Communities Act 1972 could not be 'impliedly repealed' by a later act of parliament. In that case the Merchant Shipping Act 1988, which had introduced directly discriminatory restriction on EU businesses contrary to the fundamental freedoms of the EU treaties, was effectively set aside by a court. The House of Lords introduced a distinction between acts of parliament that Dicey's theory had explicitly rejected. Dicey had said in terms that 'there is under the English constitution no marked or

\footnotetext{
52 It is not entirely clear to me that this is Lord Reed's actual view, or the view that he assumes to be the case in order to examine and ultimately dismiss Helen Mountfield's arguments. It is possible to read paragraphs 222-230 of Lord Reed's judgment as an (effective) response to counsel's self-contradictory use of the idea of an act of parliament changing the 'rule of recognition' (which was not part of the lead applicant's submissions or part of the majority's reasoning) and nothing more.

${ }^{53}$ See R. T. E. Latham, The Law and the Commonwealth (Oxford: Oxford University Press, 1949) 522-525 and R. F. V. Heuston, Essays in Constitutional Law, second edition (London: Stevens, 1964) 1-3, Sir Ivor Jennings, The Law and the Constitution, fourth edition (London: University of London Press, 1952) 146-149 and Geoffrey Marshall, Constitutional Theory (Oxford: Clarendon Press, 1971) 35-57. For more recent accounts see T R S Allan, The Sovereignty of Law (Oxford: Oxford University Press, 2013) and Pavlos Eleftheriadis, 'Parliamentary Sovereignty and the Constitution' 22 Canadian Journal of Law and Jurisprudence (2009) 267-290.

${ }^{54}$ R. v. Secretary of State for Transport, ex p. Factortame Ltd (No. 2) [1991] 1 A.C. 603.
} 
clear distinction between laws that are not fundamental or constitutional and laws which are fundamental or constitutional. ${ }^{55}$ The same thing had been stated by Wade in his original study on sovereignty.

When William Wade commented on the case more than forty years after his original article on sovereignty, he opened his essay with these words:

'When in the second Factortame case the House of Lords granted an injunction to forbid a minister from obeying an Act of Parliament, and the novel term "disapplied" had to be invented to describe the fate of the Act, it was natural to suppose that something drastic had happened to the traditional doctrine of Parliamentary sovereignty. ... When that Act was nevertheless held to prevail it seemed to be fair comment to characterise this, at least in a technical sense, as a constitutional revolution. The Parliament of 1972 had succeeded in binding the Parliament of 1988 and restricting its sovereignty, something that was supposed to be constitutionally impossible. It is obvious that sovereignty belongs to the Parliament of the day and that, if it could be fettered by earlier legislation, the Parliament of the day would cease to be sovereign'. 56

Wade was responding to a comment on Factortame by a leading judge. ${ }^{57}$ John Laws had argued that the incorporation of EU Law had not changed anything about parliamentary sovereignty. It had only introduced a new rule of 'construction' according to which European law cannot be abrogated by implied repeal. ${ }^{58}$ Wade's view was that the 'construction' view was not sufficient to explain the change, because no rule in the 1972 Act, substantive or interpretive, could override the explicit words of the 1988 Act. The later 'Queen in Parliament' ought to prevail. Wade then argued that only a higher law could limit a later parliament, just like the imperial parliament could bind colonial parliaments by virtue of the Colonial Laws Validity Act 1865 (under which colonial legislatures were able to bind their successors as to the 'manner and form' of future legislation). Wade noted that this could happen only because the enabling act was a 'higher law' under which the colonial legislature was subject to the conditions set out by the Imperial Parliament. He argued that it was possible to construct Lord Bridge's speech in the case as allowing for parliament to legislate in a way that binds its successors by creating higher law. But this was a revolutionary change to the doctrine of parliamentary sovereignty.

Wade's criticism of the 'construction' view was in my view entirely correct. Factortame cannot be explained by way of some rule of construction. The change in the structure of the public law of the United Kingdom brought about by EU law is more fundamental and is exactly as Wade described it: it requires an idea of higher law that

\footnotetext{
${ }^{55}$ Dicey, The Law of the Constitution 37.

${ }^{56}$ Sir William Wade, 'Sovereignty: Revolution or Evolution?' 112 Law Quarterly Review (1996) 568-575, at 568.

57 John Laws, 'Law and Democracy' [1995] Public Law 72

58 Laws, 'Law and Democracy' 89.
} 
constrains later parliaments. How can such a higher law be created? The answer was that parliament can create such rules. Wade's response argument appears to have convinced John Laws of its correctness.

A few years later in the case of Thoburn, John Laws had to deal with precisely this problem in his judicial capacity. His response was markedly different, as if he had accepted Wade's earlier points. The applicants in that case claimed that the Weights and Measures Act 1985 was incompatible with the requirements of a UK statutory instrument giving effect to an EU Directive requiring the use of kilograms and grams for the sale of groceries. They argued that (contrary to Factortame) the domestic law should prevail, against EU law. Informed by arguments made by Eleanor Sharpston, an EU law specialist who was then appearing as counsel for the council (and is currently an Advocate General at the Court of Justice of the EU), John Laws abandoned the 'construction' view. He accepted Wade's argument from the analogy with colonial legislation, namely that the supremacy of EU law required some kind of law higher than ordinary statutes. But Laws submitted that such a distinction was possible under the British Constitution. He thus drew a a distinction (which would have shocked Dicey), between higher and ordinary acts of parliament. He called the former 'constitutional' statutes. A constitutional statute determines how an ordinary statute is to be read:

Ordinary statutes may be impliedly repealed. Constitutional statutes may not. For the repeal of a constitutional Act or the abrogation of a fundamental right to be effected by statute, the court would apply this test: is it shown that the legislature's actual not imputed, constructive or presumed - intention was to effect the repeal or abrogation? ... the ordinary rule of implied repeal... has no application to constitutional statutes. ${ }^{59}$

In Laws' view parliament can create constitutional statutes not by following any particular process, but because of the substance of the legislation it is bringing about. Parliament knows when an act is constitutional because of its significance. In any event the courts can make their own judgment about it.

As is well known, this view was endorsed by the Supreme Court in Buckinghamshire in 2014, as discussed above. ${ }^{60}$ The Supreme Court accepted in that case that the constitution is a set of legal principles that go beyond a a mere rule of procedure. The constitution is a comprehensive set of rules and principles concerning the legitimate exercise of power in a democracy of free and equal citizens. In the absence of a written constitution outlining these rules, such rules must be found in the unwritten common law, extrapolated from concrete cases in the way that general principles emerge through the ordinary processes of legal reasoning.

\footnotetext{
59 Thoburn v Sunderland City Council [2003] QB 151, para 63.

${ }^{60} \mathrm{R}$. (on the application of Buckinghamshire CC) v Secretary of State for Transport [2014] UKSC 3, par. 207.
} 
This view of a 'legal constitution', which is law and not fact, is reaffirmed by the majority in Miller. The distinction between constitutional and ordinary acts is reaffirmed. Constitutional acts are distinguished not by the way they are made, but on account of their content. So the European Communities Act 1972 is a constitutional act because of its significance: it changed the terms of law-making in order to accommodate the EU treaties. It created a new method of law-making, whereby European institutions create laws that take effect in the UK directly without any other prior act of specific incorporation.. The fact that parliament decided to enter into this power-sharing agreement with other European states on the basis of treaties was a constitutional decision of the highest significance. This explains what Lord Bridge had already said n Factortame:

If the supremacy within the European Community of Community law over the national law of member states was not always inherent in the EEC Treaty it was certainly well established in the jurisprudence of the Court of Justice long before the United Kingdom joined the Community. Thus, whatever limitation of its sovereignty Parliament accepted when it enacted the European Communities Act 1972 was entirely voluntary. Under the terms of the 1972 Act it has always been clear that it was the duty of a United Kingdom court, when delivering final judgment, to override any rule of national law found to be in conflict with any directly enforceable rule of Community law. ${ }^{61}$

What is implicit in Lord Bridge's argument is the underlying theory of the constitution later outlined by John Laws and endorsed by the Supreme Court, according to which parliament is able to make a decision of constitutional significance. The democratic processes of lawmaking apply to law-making itself.

This democratic view of the constitution predates Dicey. It is precisely through these powers that the great constitutional statutes of the past were made. So the Bill of Rights 1689 was made by parliament in order to apply to itself and set out the proper relations between the Crown and Parliament. ${ }^{62}$ Otherwise, the Bill of Rights makes no sense. The same applies to the Act of Union. And if this was true in the seventeenth century, it must be true today. There is no reason to think that the democratic power that made these Acts possible has for any reason disappeared. If anything, it has been strengthened by universal suffrage and the recognition that fundamental human rights are to be equally held by all. Unless the constitution ossified and froze at some point since 1689, parliament continues to have the power to change its own law-making powers. This is what Factortame said. The same principle has now been affirmed by the House of Lords judgments in Jackson, ${ }^{63}$ and by the UK Supreme Court in Buckinghamshire, in Pham and now Miller.

\footnotetext{
${ }^{61}$ Factortame (No 2) [1991] 1 A.C. 603 at p. 658.

${ }^{62}$ For this historical development see Goldsworthy, The Sovereignty of Parliament, 159-220

${ }^{63} R$ (Jackson) v Attorney General [2005] UKHL 56.
} 
John Laws has explained that this change is a matter of the flexibility and adaptiveness of the common law as the law that applies to the constitution itself. The supremacy of EU law was something that could be given by parliament but of course on conditions set out by the United Kingdom constitution, so that 'the reach of European law is ultimately a function of Parliament's will; and it is of course not to be assumed that Parliament has given the European legislature carte blanche'. ${ }^{64}$ John Laws explains how this was done. EU law is dependent on constitutional statutes, although it is not dependent on ordinary statutes. In this sense it is both dependent and independent. ${ }^{65} \mathrm{It}$ is the same solution accepted in Germany, France and all the other member states of the Union: EU law is subject to the constitution, but not subject to ordinary statutes. ${ }^{66}$ It follows that Lord Reed's disjunction between a radical new 'rule of recognition' and a subordinate delegated legislation was false. It is possible under UK law to have constitutional statutes that tell us how to read ordinary statutes. Creating them or repealing them does not change the mysterious 'rule of recognition', it is just a matter of constitutional law. Parliament is empowered to create constitutional statutes.

This is then what the legal view of the unwritten constitution, as defended by John Laws and other scholars, says about the constitution as higher law. It has been accepted by the Supreme Court in every one of the constitutional cases of the last twenty five years: Factortame, Jackson, Buckinghamshire and now Miller. ${ }^{67}$. This view assumes that there is no simple rule sorting out the matters of sovereignty. The constitution is a matter of law, not a matter of fact. So Dicey and Wade were wrong about constitutional law. The constituiton's ultimate rules are legal rules, not matters of fact as suggested by Dicey, Wade and Hart. Because they are legal rules, they are subject to the ordinary practices of deliberation and argumentation as to their content. Legal deliberation determines which acts are constitutional acts and which are ordinary acts, not brute force or social pressure or convergence in conduct. For the common law doctrine of the unwritten constitution the constitution is a deliberative judgment, like all laws. ${ }^{68}$ It follows that parliamentary

\footnotetext{
64 John Laws, The Common Law constitution (Cambridge: Cambridge University Press, 2014) 70.

${ }^{65}$ This is the answer to Mark Elliot's question of 'how EU law can be an independent source of UK law while being dependent for that status upon the 1972 Act', the answer to which Elliott thinks 'is never revealed' in the majority. In my view, the answer is a matter of basic constitutional law. It is part of the common law constitution doctrine adopted by the majority, which follows exactly the principles set out in Buckinghamshire, Thoburn and Factortame. See Mark Elliot, 'Miller and the Modern British Constitution' Counsel, March 2017, 24-26.

${ }^{66}$ For a recent overview of the German law see Matthias Hong 'Human Dignity, Identity Review of the European Arrest Warrant and the Court of Justice as Listener in the Dialogue of Courts: Solange -III and Aranyosi', 12 European Constitutional Law Review (2016) 549-563.
}

${ }^{67}$ See for example T R S Allan, The Sovereignty of Law: Freedom, Constitution and Common Law (Oxford: Oxford University Press, 2015), Stephen Sedley, 'The Sound of Silence: Constitutional Law Without a Constitution' 110 Law Quarterly Review (1994) 270-291.

${ }^{68}$ For the deliberative theory of law, which reject's Hart's legal positivism and supports the idea of a deliberative law and constitution, see Ronald Dworkin, Law's Empire (London: Fontana, 1986), Ronald Dworkin, Freedom's Law: The Moral Reading of the American Constitution (Cambridge, Mass.: Harvard University Press, 1997), N. E. Simmonds, Law as a Moral Idea (Oxford: Oxford University Press, 2007) 
sovereignty or the supremacy of parliament is part of the complex rules and arguments of the common law outlining constitutional essentials, addressing all the matters that a written constitution also addresses: the powers and composition of institutions, the separation of powers, the nature of judicial review, the extent of fundamental rights and relations with international law, among others. These matters are open to determination by parliament, they are not matters of fact to be discovered in a supposed 'rule of recognition'. They are matters of law to be shaped by legislation and argued in court. c This constitutional arrangement is, after all, the result of the most important act of parliament of all, the Bill of Rights 1689 which established beyond doubt the supremacy of parliament over the King.

This is what the term 'common law constitution' means: the constitution is developed by way of the whole set of relevant materials, statutes, referenda, judicial decisions and academic argument. The position of EU law in the UK did not just change by virtue of one provision in 1972, but by virtue of the totality of acts that ratified treaties (several times since 1972 every time affirming the will of parliament to be a member of the EU), as well as the totality of statutory instruments that implemented EU Directives and the decisions of the Court of Justice of the EU given effect in the UK and recognised as equal sources of legal argument as well as the political decisions that affirmed the process of sharing of sovereignty with other nations on the basis of the rule of law and reciprocity, under the Treaties. All this material is the subject of interpretation that results in the principles of constitutional law. This is the common law constitution.

\section{Constitutional Essentials}

This is then the underlying constitutional disagreement between the majority and the minority in Miller. The government suggested and Lord Reed accepted that no major constitutional change had happened when the UK joined the EU, because the words of the 1972 Act could not bring about any such change - only a 'revolution' could, under the doctrine of simple sovereignty as accepted by Dicey, Wade and Hart (and implicitly endorsed by Lord Reed in par. 225-226). In addition, John Finnis 'conduit' metaphor sounded plausible precisely because it considered the 1972 Act to be an ordinary statute which could not make any change to sovereignty. It was thus narrowly conceived as a one-way 'conveyor belt' bringing foreign rights and duties into the law of the UK, just like the double taxation treaties do. Finnis refused to see the bigger constitutional picture, namely the fact that membership in the EU enables the UK to join a supranational institution of peace and legality which enhances the law-making powers of the UK by enabling it to co-legislate for the rest of the EU and to create

and Pavlos Eleftheriadis, Legal Rights (Oxford: Oxford University Press, 2008). For the precise ways in which Hart's theory was incapable of accommodating the common law idea of law as a practical judgment see in particular A W B Simpson, 'The Common Law and Legal Theory' A W B Simpson (ed.), Oxford Essays in Jurisprudence: Second Series (Oxford: Clarendon Press, 1973) 77. See also Pavlos Eleftheriadis, 'Hart on Sovereignty' in Luis Duarte d' Almeida, James Edwards and Andrea Dolcetti (ed), 50 Years from H.L.A. Hart's The Concept of Law (Oxford: Hart Publishing, 2013) 59-80. 
reciprocal rights in all EU citizens of whatever nationality for free movement and nondiscrimination. Strangely, John Finnis' argument did not discuss the recent cases on the reception of EU law into the United Kingdom.

The majority, by contrast, accepted that parliament can and does have a say on such major constitutional matters. It assumed that parliamentary sovereignty is a legal rule, to be changed by law through a democratic process, just like the 1689 Act did by limiting the powers of the King and establishing the rights of Parliament - precisely because it was conceived as a constitutional statute (something that the Victorians, with the exception of Maitland, forgot). This is what a common law view requires. So the majority view in Miller explicitly rejected the 'simple sovereignty' doctrine. It rejected Wade's view that adjusting to EU law has changed the so called 'rule of recognition' when it said: 'we would not accept that the socalled fundamental rule of recognition (i.e. the fundamental rule by reference to which all other rules are validated) underlying UK laws has been varied by the 1972 Act or would be varied by its repeal'. ${ }^{69} \mathrm{~A}$ few pages later the majority make the same point when they say that 'we cannot accept that a major change to UK constitutional arrangements' can be achieved by a ministerial decision. ${ }^{70}$

By contrast to Dicey, Wade and Hart, the majority declares that constitutional change can happen 'in the only way that the UK constitution recognises, namely by Parliamentary legislation'. ${ }^{71}$ The conclusion follows, they say, from 'the ordinary application of basic concepts of constitutional law to the present case'. ${ }^{72}$ As a result, the Court concludes that the incorporated EU Treaties were 'unique in their legislative and constitutional implications', because for the first time a 'dynamic, international source of law was grafted onto, and above, the well-established existing sources of domestic law: Parliament and courts'. ${ }^{73}$ Once again, the majority assumes that parliament had the power to make this possible by creating sources above the traditional sources. The Dicey-Wade-Hart doctrine of constitutional ossification has been fully and clearly rejected.

For the majority the European Communities Act did bring about constitutional change. Parliament had the power to do so and used it. This was not a revolution (as Wade suggested), but the standard operation of parliament's well known and frequently exercised constitutional powers, known to UK law since at least 1689. In 1972 and in the subsequent referendum and acts of parliament ratifying later treaties, membership in the EU was affirmed repeatedly as a reciprocal arrangement to share sovereignty with other European states. The common law view of the constitution explains that this was possible and lawful. Constitutional change in Britain is now clearly a legal change, which can happen not through a supposed change to a mysterious non-legal 'rule of recognition', but through the enactment of a

\footnotetext{
${ }^{69}$ Miller, par. 60.

${ }^{70}$ Miller, par 82.

${ }^{71}$ Miller, par. 82 (emphasis added).

72 Miller, par. 82 (emphasis added).

${ }^{73}$ Miller, par. 90.
} 
constitutional statute. Hence, the withdrawal from the EU, as the decision that breaks up this relationship of reciprocity with other European states, requires an act of parliament explicitly doing so.

It sounds a mundane point but it is not. It puts beyond doubt that the constitutional theories of Dicey, Wade and Hart are rejected. Constitutional change cannot happen in the United Kingdom through practice, evolution or change of opinion or another legal revolution', as Dicey Hart and Wade suggested. The constitution is not reducible to the social fact of a mysterious 'rule of recognition' as Hart said. Such a rule does not exist or, more precisely, the constitution has no need for it. The constitution is a set of legal principles that apply to itself. In the United Kingdom - and elsewhere where there is a legal system - the constitution is a matter of law, not a matter of public opinion or attitude. Its content is to be argued and deliberated on like all other matters of law. This is not said anywhere explicitly in the unwritten constitution, but is a constitutional essential as part of the 'basic concepts' of the constitution. Miller thus affirms what we already knew about common law constitution. In order to accommodate the constitutional position of European Union law, it has relied on a distinction - also unwritten - between 'constitutional statutes' of higher significance and ordinary statutes which until then was implicit in the unwritten structures of the British constitution. What is a constitutional statute is a matter of legal judgment, which turns on its content and not on how it was made, since all statutes are made in the same way. The constitution is a matter of law, open to legal deliberation and reasoning to be determined by the legislature, the executive and the courts working together. The United Kingdom constitution is a deliberative constitution, like all others.

\section{Conclusion: Theory and Practice}

The British experience with the unwritten constitution has turned a philosophical question about the nature of constitutions into a doctrinal one. The question is: 'what makes the constitution true law?' A written text which is made and amended according to certain special processes makes the question easy to answer in practice, as the example of France and United States show. ${ }^{74}$ Whenever there are public processes for making and amending a written constitution, lawyers can point to the text for the start of an answer. Whenever, as in the UK or Israel, a text is absent, such answers are not possible. Disagreements about the content of the constitution and its change are therefore inevitable. Dicey thought that the simple rule of sovereignty was an appropriate answer, which kept at bay the French and American models and prevented change. But he was wrong. The democratic process brought about constitutional change as a matter of law, as it did with the case of European Union law. This turned Dicey's theory into a paradox, as shown in Jackson, Buckinghamshire and Miller, because under that theory the constitution both did and did not change. At each stage, every

\footnotetext{
${ }^{74}$ This, however, does not resolve the underlying theoretical problem, because the question arises in a different form: 'where do these processes derive their authority from?' I discuss these questions in Pavlos Eleftheriadis, 'Power and Principle in Constitutional Law' 45 Netherlands Journal of Legal Philosophy (2016) 37 56.
} 
constitutional innovation had to be taken to be a singular moment of 'revolutionary' change, however peaceful and law-like it may have been.

For many years UK law remained under the spell of this 'simple fact' theory of Dicey, Wade and Hart, refusing to deal with the question of constitutional change. But the theory was never fully accepted, because it turned constitutional law into a pre-legal mystery, where routine developments took place as a exceptional matters of social fact, not as a matter of law. The courts never fully accepted this theory. In the end they rejected it altogether. In place of the rigid Diceyan formula we now have the idea of the common law constitution, which gives parliament an explicit - although perhaps not unlimited - power to shape the constitution. Accordingly, the unwritten constitution is a system of principles, whose origins lie not in a fact of sovereignty or in the identity of the underlying 'political community' but in the legal transformation of the United Kingdom three centuries ago by way of the Bill of Rights 1688, the Act of Union 1707 and other constitutional statutes that created the higher law of the constitution in line with principles of constitutional justice for equal citizens.

This is not, one should hasten to add, something unique to the unwritten constitution. The same process of theoretical adjustment through interpretation is evident in all systems, including those of a written constitution. The same dilemmas forced the French Conseil Constitutionel, for example, to go beyond the text of the constitution, in order to accept the 1789 'Declaration of the Rights of Man and Citizen' as a source of the constitution ${ }^{75}$ and the American Supreme Court to declare in Marbury $v$ Madison that it had the power to review statutes on the basis of the constitutional text. ${ }^{76}$ In both examples the courts had to come up with a theory of the essentials of the constitution above and beyond the written texts. These questions could not be answered from within the texts. This interpretive and self-reflective process of deliberation and judgment is thus inevitable in all constitutions. The United Kingdom unwritten constitution is a constitution like all others.

\footnotetext{
75 The French constitution of 1958 contained a reference in its Preamble to the Declaration of Man and Citizens, without, however, making it part of the Constitution. The Conseil Constitutionnel decided in Changes to the Budgetary Provisions of the EC Treaties case of 1970 that it was legally binding as if it were incorporated into the text (see CC decision no. 70-39 DC of 19 June 1970, Rec. 15). See also The Associations Law decision of 1971, which begins: 'In the light of the Constitution, and especially of its Preamble'. Since then, the Preamble has been treated as giving legally binding constitutional force to all the values that it mentions' (CC decision no. 71-44 DC of 16 July 1971). See John Bell, French Constitutional Law (Oxford: Oxford University Press, 1995) 66-67.

${ }^{76}$ Marbury v Madison 5 U.S. 1 Cranch 137137 (1803).
} 